Гненний; Укр. держ. акад. залізн. трансп. - Харків, 2004. $-21 \mathrm{c}$.

5. Мукмінова Т. А. Структура природної монополії на залізничному транспорті України та деякі підходи стосовно іï реформування / Т. А. Мукмінова // Вісн. ХНУ ім. Каразіна : зб. наук. пр. - 2002. -Вип. 565. - С. $79-87$

6. Arne Beck Railway Efficiency / Arne Beck, Heiner Bente, Martin Schilling // International Transport Forum Discussion Papers. - 2013. -12.

7. Encyclopedia Britannica [Електронний pecypc]. - $\quad$ Режим доступу :http://www.britannica.com/eb/article-9111233/UnitedStates United States. - Загол. з екрану.

8. Інвестиції в компанію «ІнтерБерінг» [Електронний ресурс]. - Режим доступу: . - Загол. 3 екрану.
9. Beck A. Barriers to Entry in Rail Passenger Services: Empirical Evidence for Tendering Procedures in Germany / A. Beck // European Journal of Transport and Infrastructure Research. - 2011. - Iss. 1. - P. 2041.

10. Санчес П. Эффективность, технические изменения и производительность в европейском железнодорожном секторе: Стохастический подход / П. Санчес, Д. Вилланова // Международный журн. экономики транспорта. - 2000 - № 1. - С. 55-76.

11. Аренков И. А. Бенчмаркинг и маркетинговые решения / И. А. Аренков, Е. Г.Багиев. - Санкт Петербург : Изд-во СПбУЭФ, 2001. $-94 \mathrm{c}$.

Рецензент д.е.н., професор ДНУЗТ Міщуенко М.I. Експерт редакційної колегії к.е.н., дочент УкрДУЗТ Токмакова І.В.

УДК: 656.61(477)

\title{
ДЕРЖАВНА ПІДТРИМКА СУДНОБУДІВНОЇ ГАЛУЗІ ЯК НАПРЯМОК РОЗВИТКУ ЕКСПОРТНОГО ПОТЕНЦААЛУ КРАЇНИ
}

\author{
Котлубай В.О., к.е.н., доцент (НУ «ОЮА»)
}

У статті розглядаються питання, присвячені розвитку експортного потенціалу Украӥни. Ключовим аспектом онтогенезу експортного потенціалу країни є розвиток суднобудівної галузі, що $\epsilon$ актуальним та стратегічним напрямом для будь-якої морської держави.

Суднобудування є однією з ключових галузей, яка може використовувати наш вітчизняний метал. Для відновлення суднобудування важливим також є розвиток транзитних коридорів, які йдуть через Україну.

Ключові слова: суднобудування, експорт, експортний потенціал, світова глобалізація, державна підтримка.

\section{ГОСУДАРСТВЕННАЯ ПОДДЕРЖКА СУДОСТРОИТЕЛЬНОЙ ОТРАСЛИ КАК НАПРАВЛЕНИЕ РАЗВИТИЯ ЭКСПОРТНОГО ПОТЕНЦИАЛА СТРАНЫ}

\author{
Котлубай В.А., к.э.н., доцент (НУ «ОЮА»)
}

В статье рассматриваются вопросы, посвященные развитию экспортного потенциала Украины. Ключевым аспектом онтогенеза экспортного потенциала страны является развитие судостроительной отрасли, что является актуальным и стратегическим направлением для любого морского государства.

Судостроение является одной из ключевых отраслей, которая может использовать наш отечественный металл. Для восстановления судостроения важным также является развитие транзитных коридоров, которые идут через Украину.

Ключевье слова: судостроение, экспорт, экспортный потенциал, мировая глобализация, государственная поддержкк.

(C) Котлубай В.О. 


\title{
STATE SUPPORT OF THE SHIPBUILDING INDUSTRY AS LINE OF DEVELOPMENT OF EXPORT POTENTIAL OF THE COUNTRY
}

\author{
Kotlubay V.A., candidate of economic Sciences, associate Professor \\ (National University "Odessa law Academy")
}

Different aspects of development of export potential of Ukraine are examined in the article. A key aspect of ontogeny of export potential of the country is the development of the shipbuilding industry that is relevant and strategic direction for any maritime state.

Ukraine has fairly essential resources and has high export potential of supplying the external market the products of shipbuilding (ship repair) facilities. To capture the relevant world market sectors, domestic enterprises should get to the new level of quality and competitiveness of their products. However, it can be implemented only with the active participation of the state. Efficiency of functioning shipbuilding (ship repair) facilities can be achieved only when using the full set of tools to support them.

The prospects of the domestic shipbuilding industry are confirmed by the interest of foreign companies to the Ukrainian shipbuilding industry, which is growing every year. Commercial proposals come not only from Russia, Western and Northern Europe, but even from Turkey, African countries and Persian Gulf countries.

In order not to lose the interest of foreign customers, and in order to increase the attractiveness and potential for internal customers there should be radically change of the attitude to the entire shipbuilding industry in the country. It is necessary to develop appropriate financial conditions for the shipbuilding.

Shipbuilding is one of the key industries which can use our domestic metal. To restore the shipbuilding the development of transit corridors that go through Ukraine is also important.

Keywords: shipbuilding, export, export potential, globalization, government support.

Постановка проблеми. Загальний потенціал України дозволяє їй стати однією 3 найбільших суднобудівних держав. На території України розташовано 6 великих суднобудівних підприємств. За даними Мінсоцполітики України, падіння обсягів виробництва, що спостерігалося в останні 15 років, дещо сповільнилося, проте загальний стан підприємств досить складний і вимагає рішучих дій з боку держави [1,2].

Суднобудівна галузь $є$ пріоритетною галуззю економіки країни, як один $з$ елементів загального експортного потенціалу України.

Більше 10 років тому був прийнятий Закон "Про державну підтримку суднобудівної промисловості України", головною метою якого було створення умов, сприятливих для залучення іноземних інвестицій, розвитку та ефективного використання існуючого промислового, науковотехнічного та експортного потенціалу суднобудівної промисловості України. Проте, прийняття вищезгаданого Закону не принесло суттєвого позитивного ефекту для суднобудівної галузі України.

Все це і обумовлює актуальність обраної теми дослідження.

Аналіз останніх досліджень і публікацій. Розгляду питань розвитку суднобудівної галузі присвячено досить багато публікацій та наукових видань: Котлубая О.М., Борща B.I., Письменної
К.С., Познанської І.В., Покотілова І.Ф. [1,2,3,4] та інших. Проте зміни та реформи, що відбуваються у різних галузях, вибір європейського напряму розвитку країни, вимагають актуалізації деяких питань: переглянути політику державної підтримки суднобудівної галузі, вдосконалити шляхи підвищення рівня пi конкурентоспроможності тощо.

Mema cmammi. Визначення основних проблемних питань, які знижують конкурентоспроможність суднобудівної галузі України та надання пропозицій щодо ії розвитку.

Виклад основного матеріалу. Світова глобалізація, розвиток міжнародної торгівлі створюють сприятливі умови для розвитку національної економіки, однією 3 головних складових якої $є$ експортний потенціал країни. Експортний потенціал каїни формується за рахунок потенціалу підприємств, які $\epsilon$ самостійними учасниками зовнішньоекономічної діяльності. Можна сказати, що між фінансовоекономічним успіхом та реалізацією експортного потенціалу існує пряма залежність [6].

На сучасному етапі становлення України як суверенної європейської країни особливого значення набуває необхідність утвердження іiі як дієздатної самостійної морської держави. Одним 3 напрямів для реалізації цього $\epsilon$ розвиток експортного потенціалу України одним 3 
елементів $\epsilon$ розвиток суднобудівних і судноремонтних підприємств тобто розвиток суднобудівної галузі.

Уряд України ще в 2013 р. обіцяв розробити програму підтримки суднобудування України, проте ніякі проекти урядом не були впроваджені [7].

У закордонній практиці існують різні приклади державної підтримки експортоорієнтованих підприємств, а саме: інструменти зовнішньоекономічної політики (тарифна i нетарифна політика регулювання зовнішньої торгівлі), порядок надання пільгового оподаткування, підтримка кредитування експорту, державне страхування експортних операцій та інші засоби державного регулювання тощо [8].

Галузь суднобудування є однією 3 важливіших складових економіки будь-якої морської держави, вона забезпечує баланс між попитом і пропозицією в сфері торговельного судноплавства. Якщо розглянути історію світового суднобудування, то слід зазначити, що за весь період свого існування вона практично завжди отримувала державну підтримку. Це пов'язано 3 тим, що суднобудування $\epsilon$ стратегічно важливою галуззю для країни, а також $з$ темпами зростання світової торгівлі які вона не в змозі була підтримувати.

Для стимулювання будівництва нового флоту ряд країн використовували будівельні субсидії.

У багатьох країнах (США, Японія, Німеччина, Нідерланди, Португалія, Філіппіни, Індонезія, Алжир, Бразилія, Аргентина, Мексика та інші) суднобудівні субсидії зіграли, а в деяких i продовжують відігравати значну роль у створенні конкурентоспроможного торгівельного флоту [1].

Ще одним 3 видів державної підтримки судновласників було і $є$ надання субсидій для погашення частини відсотків за кредитами. Така форма допомоги застосовувалася практично скрізь. Проте, починаючи з 2012 р. у міжнародній галузі суднобудування відбулися певні зміни в наслідок перенасичення ринку новим дедвейтом. Так в 2012 р. завершився найбільший в історії цикл суднобудування. У період з 2001 р. по 2011 р. обсяги здачі в експлуатацію нових суден з року в рік постійно зростали. Навіть після економічного спаду 2008 p. річний дедвейт суден, що спускалися на воду продовжував зростати ще три роки, завдяки замовленням, які значною мірою були розміщені до кризи.

Тільки в 2012 р. вперше 32001 р. тоннаж суден, що були здані в експлуатацію протягом року, не досяг рівня попередніх 12 місяців.

Незважаючи на таке уповільнення темпів здачі нових суден, у 2012 р. тоннаж світового флоту продовжував зростати, хоча i нижчими темпами; річні темпи зростання склали $6 \%$ проти $10 \%$ у попередньому році.

За період з 2001 р. тоннаж світового флоту збільшився більш ніж удвічі, досягнувши в січні 2013 р. 1,63 млрд. т дедвейту [9].

Однак, постійні зміни, що стосуються посилення вимог до безпеки судноплавства в тому числі до характеристик суден, вимагають додаткових замовлень на переобладнання вже існуючих суден i будівництво нових. Також Свропейська комісія представила Білу книгу, яка містить план розвитку транспортної галузі до 2020 p. [10].

Вище наведене свідчить про те, що незабаром міжнародна суднобудівна галузь може повернути собі позитивні темпи зростання.

Розвитку вітчизняних суднобудівних підприємств України, поліпшенню їх виробничих i фінансових показників перешкоджає ряд обставин:

- відсутність ефективної моделі управління галуззю і окремими підприємствами;

- нестача інвестицій і тривала стагнація виробництва, відсутність суттєвих мотивів для впровадження інновацій;

- високий рівень фізичного та морального зносу основних фондів;

- застарілі технологічні і проектні рішення;

- використання для отримання замовлень адміністративного ресурсу, а не конкурентних механізмів;

- менш сприятливі, порівняно 3 закордонними верфями, умови фінансування будівництва суден, відсутність ефективних схем кредитування виробництва;

- високий рівень податкового та митного навантаження, неефективність i корумпованість митних органів;

- відсутність бюджетного фінансування у зв'язку 3 важким фінансово-економічним становищем країни i відповідно відсутністю вільних бюджетних коштів.

На сьогоднішній день, вітчизняне суднобудування зорієнтоване переважно на виконання експортних замовлень. Вітчизняні замовлення становлять близько $10-20 \%$ від загального числа суднобудівних замовлень.

В Україні переважно іноземні клієнти замовляють корпуса суден, комплектуючи їх 
необхідним обладнанням і технічними пристроями вже у своїх країнах. Вартість українських суднобудівних робіт вище ніж в Китаї, Південній Кореї - визнаних лідерів за кількістю замовлень на світовому ринку суднобудування. Але вітчизняний виробник поки перевершує китайських і корейських за якістю.

Тим не менш перспективність вітчизняного суднобудування підтверджується інтересом іноземних фірм до українського суднобудування, який зростає 3 кожним роком. Комерційні пропозиції приходять не тільки 3 Росії, Західної та Північної Європи, але навіть 3 Туреччини, африканських країн та країн Перської затоки.

Щоб не втратити інтерес іноземних замовників, а також для того, щоб підвищити привабливість і для внутрішніх потенціальних замовників необхідно кардинально змінити ставлення до всієї суднобудівної галузі країни. Необхідно розробити відповідні фінансовокредитні умови будівництва суден. Специфіка роботи 3 закордонними партнерами полягає в тому, що всі замовлення виконуються за рахунок кредитних ресурсів, які одержуються в українських банках. Заставою в цьому випадку може бути майно, яке не завжди $є$ в наявності у підприємств. Також високі відсоткові ставки за кредитами призводять до збільшення собівартості суднобудівної продукції.

Для того, щоб на прийнятному рівні конкурувати 3 іноземними судноверфями вітчизняним підприємствам, доводиться занижувати рівень рентабельності практично до мінімального рівня. В свою чергу це призводить до відсутності коштів на технічне переозброєння виробництва, його модернізацію, ремонт обладнання [11].

3 метою розвитку підприємств суднобудівної галузі країни одним 3 варіантів може бути створення кластера. До такого кластеру повинні бути залучені усі суднобудівні (судноремонтні) підприємства України, Міністерство інфраструктури, Міністерство оборони, Міністерство економічного розвитку та торгівлі, міські ради, науково-дослідні та проектно-конструкторські інститути тощо. Такий підхід дозволить залучати і своєчасно та якісно виконувати великі замовлення, які мають стратегічне значення для України.

Першочерговими завданнями які повинні бути вирішені $є$ :

$$
\text { - оптимізація та структурні }
$$

перетворення суднобудівної галузі України;
- розвиток науково-технічного та виробничого потенціалу суднобудівної галузі;

- удосконалення нормативно-правової бази забезпечення функціонування суднобудівної галузі України;

- створення відповідних фінансовокредитних умов для підвищення рівня конкурентоспроможності вітчиняної суднобудівної галузі на міжнародному суднобудівному ринку тощо.

Також необхідно відзначити, що суднобудування є однією з ключових галузей, яка може використовувати наш вітчизняний метал. У нас зараз є проблеми зі збутом металу, при цьому металургійний комплекс - це одна 3 основ нашої економіки.

Для відновлення суднобудування важливим також $\epsilon$ розвиток транзитних коридорів, які йдуть через Україну. В умовах застосування політики розвитку та державної підтримки транспортної системи України доцільним буде будування суден на вітчизняних суднобудівних заводах.

Без державної підтримки суднобудівної галузі, в тому числі надання пільг вітчизняним замовникам при будівництві на українських верфях, конкурувати із зарубіжними партнерами вітчизняні суднобудівні підприємства будуть не спроможні.

Висновки. Стабільність національної економіки України залежить від експортного потенціалу країни. Тому питання його онтогенезу повинно стати ключовим аспектом у подальшому розвитку країни. У зв'язку з тим, що Україна $\epsilon$ морською державою, одним з головних питань, що постає перед державою $\epsilon$ розвиток морегосподарського комплексу, одним 3 ключових елементів якого $є$ суднобудівна галузь. Питанням розвитку суднобудівної галузі повинно приділятися достатньо уваги зі стороні держави, оскільки ця галузь крім того, що є елементом експортного потенціалу країни також відноситься до стратегічно важливих галузей України.

Україні, щоб остаточно не втратити свої позиції на міжнародному суднобудівному ринку необхідно реалізовувати реальні, а не декларативні заходи державної підтримки. Держава повинна здійснювати не тільки пряме фінансування підприємств суднобудівної галузі, a i удосконалювати законодавче забезпечення їx функціонування. 


\section{СПИСОК ЛІТЕРАТУРИ}

1. Котлубай А.М. Проблемы теории и практики развития морского транспорта Украины / А.М. Котлубай. - Одесса: ИПРЭЭИ НАН Украины, 2011. - 268 с.

2. Познанська суднобудівельної галузі України / I.В. Познанська, П.І. Гнатюк // Економічні інновації. - 2011. - Вип. 43. - С. 264-271.

3. Покотілов І.Ф. Принципові підходи до підвищення конкурентоспроможності суднобудівної галузі України / І.Ф. Покотілов // Управління проектами та розвиток виробництва: зб. наук. пр. - Луганськ: вид-во СНУ ім. В.Даля, 2010. - № 3(35). - C. 125-130.

4. Борщ В.І. Стан та проблеми розвитку підприємств суднобудівельної галузі промисловості України / В.І. Борщ // Економіка: реалії часу. Науковий журнал. - 2014. - № 3 (13). - С. 22-29. - Режим доступу: http://economics.opu.ua/files/archive/2014/No3/2229.pdf.

5. Письменна К.С. Стан і тенденції розвитку суднобудівної промисловості в Україні: господарсько-правовий аспект / К.С. Письменна // Вісник Національної юридичної академії України імені Ярослава Мудрого. - 2010. - № 1. C. 221-229.

6. Формирование и оценка экспортного потенциала крупных промышленных предприятий [Електронний ресурс]. - Режим доступу: http://dengifinance.ru/chastthird/formirovanye-ocenka-exportnogo-potencialapredpriyatiy.html.

7. Судостроение Украины: прошлое и настоящее языком цифр и фактов [Електронний ресурс]. - Режим доступу: http://khersonline.net/novosti/ekonomika/15467sudostroenie-ukrainy-proshloe-i-nastoyascheeyazykom-cifr-i-faktov.html.

8. Экспортный потенциал отрасли по разработке и сбыту информационнокоммуникационных технологий [Електронний peсурc]. - Режим доступу: http://www.rfej.ru/rvv/id/D00273E15/\$file/2840.pdf.

9. Review of Maritime Transport 2013 [Електронний ресурс]. - Режим доступу: http://unctad.org/en/PublicationsLibrary/rmt2013_en .pdf.

10.Относительно стратегических приоритетов реализации потенциала Украины как морского государства. Аналитическая записка НИСИ [Електронний ресурс]. - Режим доступу:

http://www.maritimebusinessnews.com.ua/news/anal ytics_and_comments/2012/06/06/16797.html.

11.На кого работают украинские судостроители? [Електронний ресурс]. - Режим доступу: http://portsukraine.com/node/923.

Рецензент д.е.н., професор НУ «ОЮА» Кібік О.М. Експерт редакційної колегії к.е.н., доцент УкрДУЗТ Назаренко І.Л.

\title{
УДК: 656.611.2
}

\section{ДИНАМИЧНОСТЬ МНОГООБРАЗИЯ В РАЗВИТИИ ТОРГОВОГО СУДОХОДСТВА}

\author{
Сенько Е. В., доцент (ОНМА)
}

В системе торгового судоходства особое место занимают трансформационные проиессы. Несбалансированная динамичность развития региональных подсистем глобальной экономики предопределяет особенности формирования производственного потенциала морских транспортных предприятий. Различаются противоречивые задачи обеспечения транспортной надежности обслуживания международного разделения труда. Отмечается интенсивность наращивания провозной способности при одновременном усилении требований к системной безопасности мореплавания. Последнее в свою очередь ограничивает возможность позиционирования новых морских государств в эффективных и капиталоемких сегментах рынка морской торговли. Поэтому следует различать особенность и формы многообразия развития торгового флота. С одной 